\title{
Mechanisms of mesenchymal stem/stromal cell function
}

\author{
Jeffrey L. Spees ${ }^{1,3^{*}}$, Ryang Hwa Lee ${ }^{2}$ and Carl A. Gregory ${ }^{2^{*}}$
}

\begin{abstract}
The past decade has seen an explosion of research directed toward better understanding of the mechanisms of mesenchymal stem/stromal cell (MSC) function during rescue and repair of injured organs and tissues. In addition to delineating cell-cell signaling and molecular controls for MSC differentiation, the field has made particular progress in defining several other mechanisms through which administered MSCs can promote tissue rescue/repair. These include: 1) paracrine activity that involves secretion of proteins/peptides and hormones; 2) transfer of mitochondria by way of tunneling nanotubes or microvesicles; and 3) transfer of exosomes or microvesicles containing RNA and other molecules. Improved understanding of MSC function holds great promise for the application of cell therapy and also for the development of powerful cell-derived therapeutics for regenerative medicine. Focusing on these three mechanisms, we discuss MSC-mediated effects on immune cell responses, cell survival, and fibrosis and review recent progress with MSC-based or MSC-derived therapeutics.

Keywords: Multipotent stromal cell, Mesenchymal stem cell, Paracrine, Tunneling nanotube, Mitochondria transfer, Microvesicle, Exosome

Abbreviations: CM, Conditioned Medium; COX2, Cyclooxygenase 2; ECM, Extracellular Matrix; EV, Extracellular Vesicle; HGF, Hepatocyte Growth Factor; HO-1, Heme-oxygenase-1; IDO, Indoleamine-2,3-dioxygenase; IGF, Insulinlike Growth Factor; IL, Interleukin; LPS, Lipopolysaccharide; miRNA, MicroRNA; MLR, Mixed Lymphocyte Reaction; MSC, Multipotent Stromal cell/Mesenchymal Stem Cell; mtDNA, Mitochondrial DNA; NFkB, Nuclear Factor Kappa-B; OGT, O-GICNAC Transferase; PGE2, Prostaglandin E2; SDF-1, Stromal Cell-derived Factor-1; TGF $\beta$, Transforming Growth Factor Beta; $T_{h}$, T Helper; TLR, Toll-like Receptor; TNFa, Tumor Necrosis Factor Alpha; TNT, Tunneling Nanotube; Treg, Regulatory T Cell; TSG, TNF-stimulated Gene; VEGF, Vascular Endothelial Growth Factor
\end{abstract}

\section{Background}

Mesenchymal stem cells, also referred to as multipotent stromal cells or mesenchymal stromal cells (MSCs), have been the subject of intense scientific investigation since their initial discovery by Alexander Friedenstein in the late 1960s [1-5]. In their early studies, Friedenstein and colleagues demonstrated that MSCs, likely originating from the mesoderm, had the capacity to differentiate into a variety of mesenchymal tissue lineages such as osteoblasts, chondrocytes, and adipocytes. These observations sparked a substantial degree of interest in the potential application of MSCs for the repair of serious

\footnotetext{
* Correspondence: jspees@uvm.edu; CGregory@medicine.tamhsc.edu 'University of Vermont, Burlington, VT, USA

${ }^{2}$ Institute for Regenerative Medicine, Texas A \& M University College of Medicine, 206 Olsen Blvd., Room 228, MS1114, College Station, TX 77845, USA

Full list of author information is available at the end of the article
}

connective tissue trauma and disease [6-10]. It was originally hypothesized that, upon administration, MSCs would migrate to sites of injury, engraft, and differentiate into functional cells, resulting in regeneration of damaged or diseased connective tissues (Fig. 1a). Surprisingly, results from hundreds of animal studies and many human trials conducted over the past few decades have challenged this classic paradigm. In short, while MSCs were found to exhibit a remarkable degree of efficacy in a variety of disease models, it became increasingly apparent that the cells did not engraft in significant numbers or for durations sufficient to explain the results in terms of tissue replacement [11-15]. More surprisingly, MSCs were reported to engraft and differentiate into functional cells of tissues that did not originate from mesoderm $[16,17]$, questioning the long-established dogma that differentiation of adult stem cells is typically restricted 
a. Differentiation of MSCs to replace cells.

b. MSC/cell fusion.
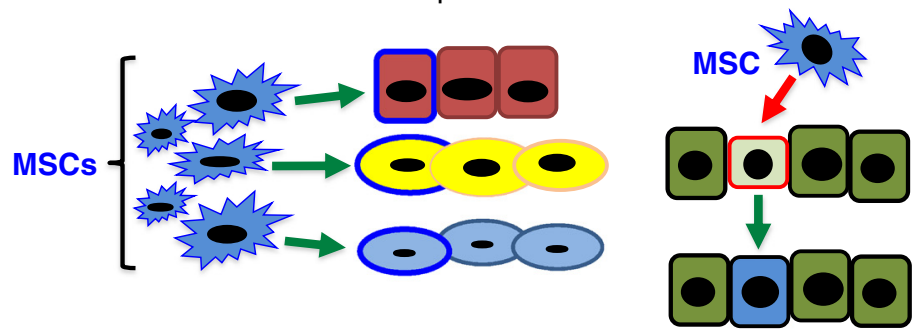

C. Paracrine activity of MSCs that promotes tissue rescue/repair.

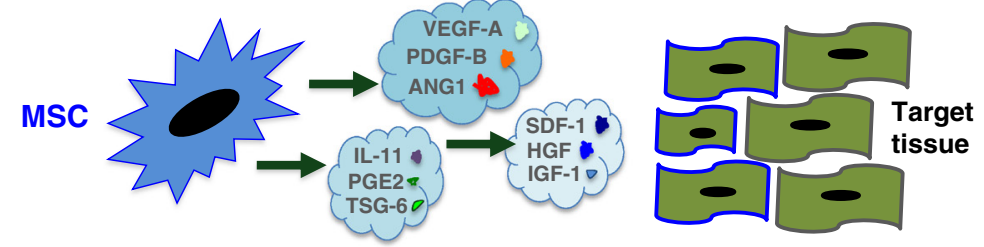

d. MSC-mediated transfer of organelles and/or molecules by TNTs.

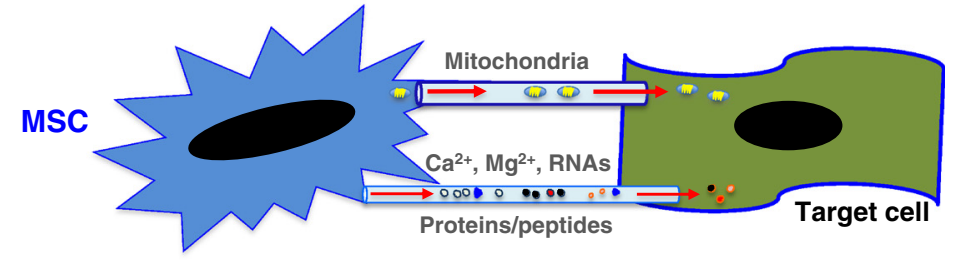

e. Transfer of molecules from MSC-derived exosomes or microvesicles.

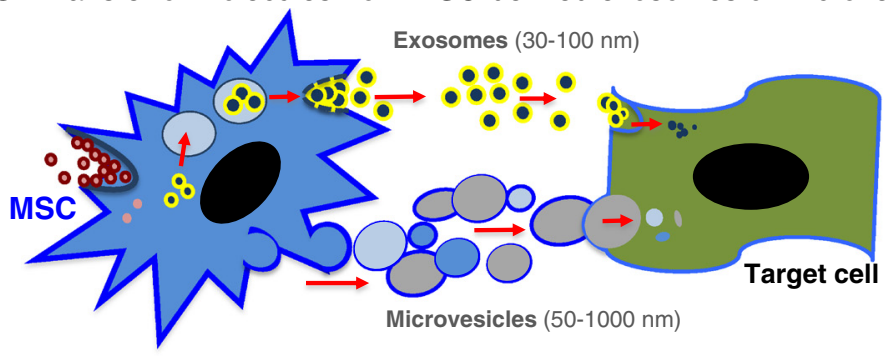

Fig. 1 MSCs rescue and/or repair injured cells and tissues by diverse mechanisms. a Differentiation into replacement cell types. b Rescue of damaged or dying cells through cell fusion. c Secretion of paracrine factors such as growth factors, cytokines, and hormones. VEGF vascular endothelial growth factor, PDGF platelet-derived growth factor, ANG1 angiopoietin-1, IL-11 interleukin-11, PGE2 prostaglandin E2, TSG-6 TNF-stimulated gene-6, SDF-1 stromal-derived factor-1, HGF hepatocyte growth factor, IGF-1 insulin-like growth factor-1. d Transfer of organelles (e.g., mitochondria) and/or molecules through tunneling nanotubes (TNTs). $\mathrm{Ca}^{2+}$ calcium, $\mathrm{Mg}^{2+}$ magnesium. e MSC-mediated transfer of proteins/peptides, RNA, hormones, and/or chemicals by extracellular vesicles such as exosomes or microvesicles. Exosomes are generated through the endocytic pathway and released through exocytosis. By contrast, microvesicles are produced by cell surface budding and released directly from the plasma membrane. Note that the figure is not drawn to scale. Also, use of mechanisms a-e is not equivalent. For example, for MSCs administered intravenously, use of mechanism c is likely more relevant than are mechanisms (a) or (b)

to tissues derived from their germ layer of origin [18-20]. Later studies confirmed that the majority of results describing cross-germ line differentiation of MSCs could be ascribed to limitations in methodology or cell fusion events (Fig. 1b) [21-23]. Still largely unsolved, the mystery of efficacy without long-term engraftment, especially in non-mesodermal tissues, remains a source of considerable debate $[24,25]$. In retrospect, a partial explanation for the benefits of MSC administration traces back to some of the very first observations made with bone marrow stromal cells. In the 1970s, Dexter and colleagues were the first to demonstrate that adherent stromal cells from bone marrow (later identified as MSCs) could sustain the growth, viability, and multipotent status of hematopoietic stem cells in long-term co-cultures that lacked growth factor supplementation [26-29]. Of particular interest was that the cultures achieved homeostasis with the self-renewal of progenitor cells balanced against the development of committed hematopoietic cells. These initial studies suggested that MSCs had the capacity to sustain the growth and 
viability of certain cell types through secretion of so-called trophic factors and even presented the notion that they could regulate certain facets of the immune system.

In an effort to reconcile discrepancies between the modest frequency and duration of engraftment with their remarkable healing properties, a contemporary view of MSC functionality is taking form. Rather than assuming long-term engraftment and differentiation, new hypotheses indicate that MSCs heal injured and diseased tissues/organs using alternative modes of rescue and repair that enhance cell viability and/or proliferation, reduce cell apoptosis, and, in some cases, modulate immune responses. The alternative modes of repair by MSCs include paracrine activity of secreted growth factors, cytokines, and hormones (Fig. 1c), cell-cell interactions mediated by tunneling nanotubes (TNTs; Fig. 1d), and release of extracellular vesicles (EVs) that contain reparative peptides/proteins, mRNA, and microRNAs (miRNAs; Fig. 1e). The purpose of this review is to examine and discuss key progress and important issues within this rapidly expanding area of regenerative medicine.

\section{Paracrine effects of administered MSCs Immune modulation by MSCs}

Some of the first evidence that MSCs could actively blunt immune responses originated from the results of mixed lymphocyte reaction (MLR) assays performed ex vivo [30-36]. These assays are based on the observation that $\mathrm{T}$ cells from preparations of immunologically mismatched peripheral blood mononuclear cells proliferate rapidly when mixed together under appropriate conditions [37, 38]. Results from MLR assays showed that Tcell expansion could be inhibited by the addition of MSCs to MLRs. While the majority of cell culture studies to date agree that such observations are mediated by MSC-derived soluble factors that do not cause T-cell apoptosis, several alternative mechanisms have also been proposed. Di Nicola et al. [31] employed a series of antibody blocking assays to implicate the role of transforming growth factor beta (TGF $\beta$ ) and hepatocyte growth factor (HGF) whereas Aggarwal et al. [32] proposed a role for prostaglandin E2 (PGE2) based on their ability to ablate inhibitory responses with cyclooxygenase 2 (COX2) inhibitors. Aggarwal et al. further proposed that the secretion of PGE2 and related factors induced dendritic cells to up-regulate the anti-inflammatory cytokine interleukin (IL)10 while reducing the secretion of proinflammatory tumor necrosis factor alpha (TNF $\alpha$ ) and IL12. This, in turn, initiates a shift in the ratio of $T$ helper $\left(T_{h}\right)$ cells from a pro-inflammatory $T_{h} 1$ subtype to an anti-inflammatory $T_{h} 2$ subtype. This was accompanied by the differentiation of naive $\mathrm{T}$ cells to an immunoregulatory regulatory $\mathrm{T}$ cell $\left(\mathrm{T}_{\text {reg }}\right)$ phenotype, thereby reducing the overall number of $\mathrm{T}_{h}$ cells. Similarly, Akiyama et al. [39] showed that MSCs could induce apoptosis of inflammatory $\mathrm{T}$ cells through activation of the Fas-Fas ligand axis. During this process, MSCs recruited additional $\mathrm{T}$ cells by secretion of monocyte chemotactic protein-1 (MCP-1) as part of a positive feedback loop. Apoptotic T-cell debris then activated phagocytes to secrete TGF $\beta$, resulting in the differentiation of naive $T$ cells into $T_{\text {reg }}$ cells that can promote systemic immune tolerance [39]. In an alternative model, Meisel et al. [33] proposed an intriguing mechanism whereby MSC-derived indoleamine-2,3-dioxygenase (IDO) catalyzes the conversion of tryptophan to kynurenine in an interferon gamma-dependent manner. In turn, the kynurenine inhibits T-cell proliferation [40, 41]. This mechanism was later confirmed by utilizing the IDO antagonist 1-methyl-L-tryptophan [42]. In a series of experiments performed by Waterman et al. [43], it was reported that MSCs could be induced to express enhanced levels of IDO and PGE2 by transient stimulation of toll-like receptor (TLR)3 with polyinosinic-polycytidylic acid (poly I:C). MSC-mediated IDO activity has also been shown to enhance kidney allograft tolerance in mouse models through a mechanism involving $\mathrm{T}_{\text {reg }}$ up-regulation, demonstrating that IDO-mediated mechanisms of immune modulation can indeed occur in vivo [44]. Nitric oxide [45], galectin-1 and semaphorin-3A [46] have also been implicated as MSC-derived modulators of T-cell proliferation, but it is noteworthy to add that nitric oxide has only been shown to function as an MSC modulator in the murine system.

MSCs also have the capacity to modulate the activity of macrophages. This effect was initially described ex vivo using macrophage cultures stimulated with TLR ligands such as lipopolysaccharide (LPS), zymozan, or polyinosine-polycytidylic acid (poly I:C); these simulate the effects of bacterial or viral infection [47, 48]. When macrophages are challenged with such agents, they secrete inflammatory factors such as TNF $\alpha$, IL1 $\beta$, IL6, and reactive oxygen species. In the presence of MSCs, however, the ability of activated macrophages to secrete inflammatory factors was attenuated [32, 49]. Of interest, these observations were explained, in part, by MSCmediated secretion of the extracellular protein TNF $\alpha$ stimulated gene protein (TSG)6 [50]. In this model, exposure to zymozan caused cultured macrophages to secrete high levels of TNF $\alpha$ and other inflammatory mediators via the TLR2-nuclear factor kappa-B (NFkB) axis. TNF $\alpha$ activates TSG6 expression by MSCs and engages a negative feedback loop by inhibiting NFkB via activation of the CD44 receptor. Several in vivo studies have confirmed that MSC-derived TSG6 acts via the CD44 receptor to inhibit NFkB activity in macrophages, dendritic cells, and $\mathrm{T}_{h}$ cells in models of peritonitis [50], diabetes [51], and 
corneal transplant rejection [52]. In addition to the action(s) of TSG6, MSC-derived PGE2 has also been demonstrated to have potent effects on macrophages in vivo. In a murine model of sepsis, Nemeth et al. [53] demonstrated that, upon activation by LPS or TNF $\alpha$, MSCs secreted PGE2. This caused the release of anti-inflammatory IL10 by macrophages and improved cell survival. Indeed, the role of PGE2 in MSC-mediated macrophage modulation is a common theme in many culture models $[54,55]$. In an alternative mechanism proposed by Chen et al. [56], placental human MSCs inhibited the interaction of TLR4 with a key effector molecule, MyD88 [48], resulting in inhibition of secretory factors by macrophages. This process was inhibited by addition of a COX2 inhibitor, suggesting that the process was PGE2-dependent.

MSCs were reported to modulate the proliferation, differentiation, and immunoglobulin secretion of B cells without induction of apoptosis [57]. Transwell assays separating the two cell types but allowing for exchange of secreted factors showed that such MSC-mediated effects derived, in part, from the paracrine activity of soluble factors secreted by MSCs. These experimental results have since been replicated using purified B cells and unpurified preparations of peripheral blood mononuclear cells [58-60]; however, the paracrine mechanism was recently challenged by a co-culture study that suggested physical interaction between $\mathrm{T}$ cells and MSCs was necessary for MSCs to inhibit the activities of B cells [61]. Using a mouse model of allergy, Nemeth et al. [62] reported that MSC-derived TGF $\beta$ was critical in suppressing B-cell mediated allergic responses in vivo. They speculated that MSCs may recruit $\mathrm{T}_{\text {reg }}$ cells that downregulate allergy-specific cytokine and immunoglobulin production as well as lung eosinophil infiltration. Consistent with their immune-modulatory properties, efficacy with MSC treatment has been demonstrated in a variety of inflammatory models of disease, including arthritis [63], Crohn's disease [64], multiple sclerosis [65, 66], myocardial infarction [14], diabetes [51, 67], graft versus host disease [34, 68, 69], and corneal rejection [52].

\section{Promotion of cell survival by MSCs}

In addition to the paracrine effects of MSCs on immune cells, they also secrete a diverse repertoire of factors that support cell survival, including growth factors, cytokines, and extracellular matrix (ECM). Together, the components of the MSC secretome have the theoretical capacity to rescue injured cells, reduce tissue damage, and accelerate repair. This is exemplified by their natural roles as reticular cells that support the hematopoietic stem cell niche $[26-28,70,71]$ and as vascular pericytes that support endothelial cells $[72,73]$. The observation that MSCs can be isolated from a wide variety of tissues, such as bone marrow, adipose, ligament, skin, placenta, dental pulp, synovium, placenta, umbilical cord, and other fetal tissues [72, 74], lends support to the concept that they function endogenously as stromal support cells.

The pro-survival effect(s) of the MSC secretome on other cell types was first recognized through studies of long-term bone marrow cultures [26-29, 75] and embryonic cells [76]. Collectively, these cell culture studies provide for an attractive, paracrine-based explanation for the ability of MSCs to promote healing across a broad range of developmentally unrelated tissues and for myriad diseases and injury types. Detailed analysis of the MSC transcriptome and proteome has confirmed that they secrete a vast repertoire of paracrine pro-survival factors commonly referred to as trophic factors or mediators [77-82]. Of interest, the MSC-secreted factors comprise a diverse group of soluble peptides and proteins with complementary set(s) of biological activities that can accelerate progenitor cell self-renewal, stimulate angiogenesis, and minimize apoptosis and/or inflammation. Despite several decades of research and progress, the specific paracrine mechanisms by which administered MSCs improve cell survival and self-renewal under particular contexts of tissue rescue/repair remain largely undefined [75, 77].

In line with the traditional model of paracrine biology whereby cells secrete factors that regulate adjacent cells, it was initially thought that engrafted MSCs readily migrated into injured tissue and then remained to orchestrate repair. For many models of tissue injury, however, what was originally perceived as "MSC migration" turned out to be far less directed (e.g., non-specific, transient trapping of MSCs within the microvasculature and capillary network). Of particular interest, depending on their relative size (i.e., diameter), the majority of intravenously administered MSCs will typically lodge in the lung microvasculature upon the first pass through the circulation, regardless of the presence or absence of lung-specific injury. Notably, after intravenous MSC infusion, paracrine factors released into the blood by circulating MSCs or from trapped MSCs may indirectly influence survival signaling and the fate of distal cells previously compromised by injury or disease. Thus, for effect, paracrine factors produced by MSCs appear not to depend on long-term MSC engraftment, nor do they require the unlikely differentiation of mesodermal progenitors into tissues of ectodermal or endodermal lineages.

Some of the best evidence supporting an indirect role for MSCs in the repair of tissues/organs originates from studies of heart with infarction. In a rat model of myocardial infarction, MSCs modified with the gene encoding protein kinase B (a.k.a. Akt) engrafted into the myocardium, reduced pathological remodeling, and 
improved cardiac function [83]. The observed efficacy was later attributed to a paracrine effect mediated by secreted frizzled related protein (sFRP), a Wnt signaling inhibitor that reduces cardiomyocyte apoptosis [84-86]. Since these studies, a number of additional mechanisms for the paracrine action of MSC-derived factors on cardiac repair have been proposed, including secretion of angiogenic factors [87-89], stromal cell derived factor-1 (SDF-1) [90], and Jagged/Notch signaling [89, 91]. Of interest, MSC-mediated improvements in cardiac function could be achieved without long-term engraftment of MSCs [11]. Using a different approach, MSCconditioned medium was employed to prime cardiac stem/progenitor cells prior to cardiac grafting in a rat model of myocardial infarction. The conditioned medium $(\mathrm{CM})$ improved cardiac stem cell engraftment through mechanisms involving connective tissue growth factor and insulin signaling [92].

The role of MSCs in the protection of other damaged tissues has also been demonstrated. For example, intraperitoneally and intravenously administered MSCs from murine bone marrow and adipose tissue had a protective effect in a cisplatin-induced acute kidney injury (AKI) model [93], as evidenced by a reduction in the apoptosis of tubule cells and improved renal function. This effect appeared to be mediated by secreted factors since the results could be repeated by intraperitoneal administration of CM generated from the MSCs (MSC-CM). In contrast, Xing et al. [94] reported that murine MSC-CM containing HGF, vascular endothelial growth factor (VEGF)-A and insulin-like growth factor (IGF)-1 failed to protect the kidneys of mice against ischemiareperfusion injury, whereas live MSCs had a significant protective effect. This is one of several examples in the field where apparently minor differences in the cell source, the culture conditions, duration of medium conditioning, and dosage can profoundly affect outcome. Such complexities have made elucidation of the mechanism(s) responsible for the protective effect of MSCs on kidney tissue challenging, but some progress has been made. For example, Zarjou et al. [95] demonstrated that the stress-responsive enzyme heme-oxygenase-1 (HO-1) played a role by utilizing MSC from bone marrow of $\mathrm{HO}-1^{-1-}$ mice. In this study, $\mathrm{HO}-1^{+/+}$MSC-CM rescued pathology associated with cisplatin-induced AKI, while HO- $1^{-1-}$ MSC-CM was ineffective. The authors attributed the difference in effect to enhanced levels of SDF-1, VEGF-A, and HGF in the HO- ${ }^{+/+}$MSCs. Indeed, immunological and transcriptional blocking experiments both confirm a protective role for VEGF-A [96-98] and IGF-1 [99] in mice with AKI and for VEGF-A in rats with cerebral ischemia (stroke) [100].

The utility of MSCs and their secreted products to protect cells and to foster tissue repair has been demonstrated in numerous efficacy-based studies across a broad range of tissue injury and disease models. While a comprehensive summary of the associated literature is beyond the scope of this review, some key examples of MSC-derived benefits include facilitation of wound healing [101], improved treatment of diabetes [102], enhancement of bone repair [103, 104], and effect(s) on cancer [105].

\section{Effects of MSCs on fibrosis}

Fibrosis is generally defined as a an accelerated accumulation of ECM factors (predominantly collagen type I) that prevents the regeneration of tissue. It can occur in virtually any tissue as a result of trauma, inflammation, immunological rejection, chemical toxicity, or oxidative stress. Current clinical strategies generally have poor outcomes in terms of efficacy and adverse effects [106]. Given the immunomodulatory and trophic properties of MSCs, they have become attractive candidates for the treatment of fibrosis and preclinical studies suggest they have a promising level of efficacy in a variety of models. While the anti-fibrotic effects of MSCs are likely to overlap with their anti-inflammatory and angiogenic properties, the specific mechanisms remain poorly understood. Nevertheless, a comprehensive review by Usuner et al. [107] suggests that their modes of action seem to fall under four categories: i) immune modulation, ii) inhibition of TGF $\beta$-mediated differentiation of various cells types into ECM-secreting myofibroblasts by epithelial to mesenchymal transition, iii) inhibition of oxidative stress, and iv) matrix remodeling. For example, Ortiz et al. demonstrated that systemic murine MSC administration attenuated fibrosis in a bleomycin-induced lung injury model [108]. This was achieved through MSC-mediated secretion of IL1 receptor antagonist, which reduced infiltration of lymphocytes and neutrophils and their production of inflammatory and fibrotic mediators such as IL1 and TNF $\alpha$. Using the same model, it was recently reported that MSCs had the capacity to inhibit fibrosis through the action of the secreted protein stanniocalcin-1 (STC-1) [109]. The authors demonstrated that STC-1 acted in multiple ways by reducing the secretion of collagen by fibroblasts, by reducing TGF $\beta$ output by endothelial cells and also through alleviating oxidative stress by uncoupling mitochondrial respiration via the induction of uncoupling protein 2. Using a model of chronic kidney injury, Huuskes et al. [110] demonstrated that MSCs improved kidney morphology and functionality when co-administered with the putatively anti-fibrotic hormone recombinant human relaxin (serelaxin). In this system, MSCs and serelaxin acted synergistically to reduce TGF $\beta$-induced myofibroblast differentiation and collagen deposition while increasing the level of matrix metalloproteinase 2 (MMP2), a collagen-degrading enzyme. 


\section{Transfer of mitochondria by TNTs and microvesicles Discovery of TNTs}

Rustom et al. [111] first reported TNTs as a communicating intercellular transport network formed in cultures of transformed cells (human 293 cells and rat PC12 cells) as well as primary cells from rat kidney. Endocytic organelles (lysosomes) and vesicles were shown to move through thin, 50-200 nm diameter filaments that stretched between cells. Incubation of cells in the inhibitor latrunculin B demonstrated a requirement for polymerized F-actin in TNT formation. Onfelt et al. [112] reported TNTs in human immune cells (e.g., natural killer cells, macrophages, and B cells) and later demonstrated that TNTs between macrophages had different properties and potentially differing functions; they observed thin filaments containing F-actin and also a thicker subset ( 0.7 microns) that contained both F-actin and microtubules. The thicker TNT subset was shown to transport mitochondria and lysosomal vesicles [113]. Other studies demonstrated that some TNTs were actinomyosin-dependent $[114,115]$. For example, the Gerdes group showed that kidney cells treated with S(-)-blebbistatin, a myosin II-specific inhibitor, increased the number of TNTs formed and also organelle transfer, whereas a general myosin inhibitor increased TNT number but significantly reduced organelle transfer [114].

\section{Discovery of mitochondrial transfer by cultured MSCs}

The first evidence that transfer of mitochondria might benefit injured target cells came from studies of human MSCs co-cultured with a unique lung epithelial cell line that lacked functional mitochondria (A549 ${ }^{\text {rho }}$ cells) [116]. Utilizing a complementation screen to detect mitochondrial transfer and resulting cell growth, the Prockop group reported that human MSCs could restore aerobic respiration to A549 ${ }^{\text {rho }}$ cells by transfer of mitochondria or mitochondrial DNA (mtDNA). Mitochondrial transfer from MSCs to rescued A549 ${ }^{\text {rho }}$ cells was demonstrated by tracking genetic tags (i.e., mtDNA and nuclear DNA) and by time-lapse photomicroscopy of MSCs transduced with lentiviral vectors to target DsRed2 to mitochondria [116]. MSCs are now understood to transfer mitochondria to several different cell types, including epithelial cells, endothelial cells, and cardiac myocytes [117]. Such transfers are particularly evident when the potential target cells are injured or under stress. For example, MSCs were recently shown to prevent apoptosis in endothelial cells by transferring mitochondria during hypoxic/ischemic stress [118].

\section{TNT formation and mitochondrial transfer in vivo}

The first evidence that TNTs could form in vivo came from studies of the eye. Using wild-type, eGFP chimeric mice, and $\mathrm{Cx} 3 \mathrm{cr} 1(\mathrm{GFP})$ transgenic mice and confocal microscopy tracking, Chinnery et al. [119] documented membrane nanotubes that formed between bone marrowderived MHC class $\mathrm{II}(+)$ cells in whole-mounted corneal tissue. Notably, they observed an increase in TNT frequency during corneal injury or inflammation. In a followup study with live imaging of myeloid cells in inflamed corneal explants from Cx3cr1(GFP) and CD11c(eYFP) transgenic mice, Seyed-Razavi et al. [120] showed de novo formation of nanotubes at a rate of $15.5 \mu \mathrm{m} / \mathrm{min}$. These results demonstrated that TNTs could form in the absence of actual cell-cell contact and, furthermore, that they could then be directed from one cell toward another. Additional evidence for in vivo mitochondria or mtDNA transfer between cells came from studies of a remarkable canine transmissible venereal tumor that had persisted in feral dog populations for about 10,000 years. Rebbeck et al. [121] showed that the transmitted tumor cell line had obtained mitochondria (mtDNA) from multiple canine hosts over time. They suggested that fitness/persistence of canine transmissible venereal tumor benefited from the acquisition of host-derived mtDNA and through shedding of mutant and/or damaged mtDNA that could negatively impact mitochondrial biogenesis. Importantly, multiple research groups have shown that intercellular transfer of organelles and mtDNA is not limited only to the animal kingdom. Intercellular organelle trafficking and horizontal gene transfer in plants has been reported for both plastids [122] and mitochondria [123].

\section{Proteins shown to control transfer of mitochondria by MSCs after tissue injury}

Several recent studies have provided compelling evidence that administered MSCs can transfer mitochondria in vivo and, furthermore, that mitochondria transfer from MSCs can rescue injured pulmonary cells and ameliorate lung injury. Islam et al. [124] demonstrated that airway instillation of human MSCs could reduce LPS-mediated lung injury, in part, through transfer of mitochondria. Using live optical imaging, they documented transfer of vesicles containing labeled mitochondria from MSCs to alveolar epithelial cells that increased alveolar ATP levels and cell survival. Unlike wild-type MSCs, MSCs genetically modified for connexin 43 that were incapable of forming gap junctions and MSCs with dysfunctional mitochondria did not reduce acute lung injury [124].

Recent data from a cigarette smoke-induced model of lung injury suggest that donor source and age may affect repair by mitochondria transfer by MSC. Li et al. [125] found that transplantation of MSCs derived from induced pluripotent stem cells may provide enhanced repair after transplantation by virtue of increased TNT formation and mitochondria transfer relative to adultderived MSCs. 
Using loss- and gain-of-function approaches, Ahmad et al. [126] elegantly demonstrated that Miro-1, an outer mitochondrial membrane Rho-like GTPase, regulated the amount of mitochondrial transfer from MSCs to cultured lung epithelial cells. Enhanced expression of Miro1 was shown to increase transfer of mitochondria from MSCs and treatment of mice with MSCs overexpressing Miro-1 reduced Rotenone lung injury and airway hyperresponsiveness and negative remodeling in several models of asthma [126].

Regulators of mitochondria transport identified in other cell types that may orchestrate mitochondrial transfer by MSCS In addition to Miro-1, other proteins known to regulate intracellular mitochondrial dynamics (e.g., fusion, fission, tethering, and trafficking) $[127,128]$ may also promote or inhibit intercellular mitochondria transfer. Miro-1 and Miro-2 belong to a group of dynamin-related proteins that regulate mitochondrial division and fusion. They interact with TRAK1 and TRAK2 (identified as Milton in Drosophila), adaptor proteins that recruit kinesin motor proteins to mitochondria. The resulting adaptor-motor protein complex shuttles mitochondria along microtubules and was demonstrated to be critical for neuronal transport of mitochondria to axons, dendrites, and synapses [129-131]. Mitofusin 1 and 2 may also regulate mitochondria transfer as they are known to interact with Miro-1 and Miro-2 as well as TREK1/ TREK2 in the adaptor-motor protein complex [132]. Perhaps not surprising, motor proteins are likely to be required for generation of some forms of TNTs. Myo-X (Myo10) is a myosin motor protein that localizes to the ends of cellular filapodia. It is unique in that it does not require substrate attachment to induce filapodia extension [133]. Co-culture studies in neuronal cells demonstrated that Myo10 was required for TNT formation from filapodia and overexpression of Myo10 resulted in increased TNT formation and vesicle transfer between cells [134].

Although the damage/injury signals that initiate mitochondrial transfer have yet to be identified, it is plausible that differences in intracellular $\mathrm{Ca}^{+2}$ or energy stores (e.g., glucose, ATP) may play a role in directing one cell to transfer mitochondria to another. For example, intracellular movement of mitochondria is highly sensitive to cytosolic $\mathrm{Ca}^{+2}$ levels. Wang and Schwartz [135] elegantly demonstrated that $\mathrm{Ca}^{+2}$ promotes Miro to interact with the motor domain of kinesin, thus blocking kinesin from the microtubule. Accordingly, mitochondria transfer from cell to cell may be affected by differences in intracellular $\mathrm{Ca}^{+2}$ concentration and/or localization. Consistent with this concept, TNTs have been shown to transfer $\mathrm{Ca}^{2+}$ and even electrical signals to neighboring cells through TNT-associated gap junctions [136, 137]. In addition, the level of available nutrients can alter movement of mitochondria. In neurons, Pekkurnaz et al. [138] reported that extracellular glucose and the enzyme O-GlcNAc transferase (OGT) affect mitochondrial motility by altering GlcNAcylation of Milton, an OGT substrate. As OGT activity is dependent on glucose, increased glucose was shown to decrease mitochondrial motility.

Of special interest, several reports indicate regulatory overlap or some form of integration between TNT formation and endosomal trafficking, as both interact with components of the exocyst complex that regulates vesicular transport from the Golgi apparatus to the plasma membrane $[139,140]$. For example, Hase et al. [141] reported that $\mathrm{M}$-sec, part of the exocyst complex, interacted with the small GTPase RalA and was required for TNT formation in a macrophage cell line. Furthermore, they showed that $\mathrm{M}$-sec expression could induce cell protrusions de novo, some of which formed TNTs with adjacent cells. Subsequently, Schiller et al. [142] found that the transmembrane MHC class III protein leukocyte specific transcript 1 (LST1) was also required for TNT formation. At the cell membrane, LST1 was shown to interact with $\mathrm{M}-\mathrm{Sec}$, myosin, and myoferlin and also to recruit RalA, promoting its interaction with the exocyst complex [142]. Notably, some mechanisms (e.g., proteins) controlling TNT formation and/or mitochondrial transfer may be specific to specialized cell types such as neurons. However, in light of the conserved nature of intracellular adaptor/kinesin motor protein complexes, mitochondrial dynamics, and endosomal trafficking, it is probable that many mechanisms that control TNT formation and/or mitochondrial transfer are similar between many cell types, including MSCs.

\section{Modifying mitochondrial transfer and/or mitochondria for clinical application}

For future clinical application, harnessing mitochondrial transfer in a controlled and predictable manner will likely require further mechanistic insight. Importantly, recent advances in targeting of DNA to mitochondria may provide new tools to track or even perhaps to genetically alter mitochondria by modifying mtDNA as opposed to nuclear genes for proteins targeted to mitochondria (e.g., genes for mitochondrial membrane proteins). For example, Yu et al. [143] restored ATP synthesis in cells carrying mutant mtDNA for human NADH ubiquinone oxidoreductase subunit 4 (ND4) by infecting cells with an adeno-associated virus capsid (VP2) fused to a mitochondrial targeting sequence and the wild-type ND4 mitochondrial gene sequence. Following recent successful testing in non-human primates and human eyes ex vivo, the innovative method may soon be applied in clinical trials for treatment of Leber 
hereditary optic neuropathy, a disease caused by a mutation in the ND4 mitochondrial gene [144].

Despite the potential benefits of mitochondrial transfer or other TNT-mediated effects, it is worth noting that cell-cell communication by way of TNTs may also have some negative consequences. In contrast to their potential therapeutic benefits, TNTs also have potential to act as disease vectors for transmission of HIV/AIDS [145], bacteria [113], Prions [146], and oncogenic miRNAs [147].

\section{Transfer of RNAs and other molecules by EVs}

The general term "extracellular vesicle" (EV) refers to membrane-bound vesicles released from most, if not all, somatic cell types (reviewed in $[140,148,149]$ ). Together, the EVs include exosomes, 30-100-nm plasma membrane-coated vesicles of endocytic origin; microvesicles, 50-1000-nm vesicles of non-endocytic origin; and apoptotic bodies, $1-5-\mu \mathrm{m}$ vesicles released during membrane blebbing of apoptotic cells [150].

Cellullar exosomes are released when multivesicular bodies traffic to and fuse with the plama membrane in a regulated manner. Exosomes were first identified and isolated from cultures of normal and transformed cells during the 1980s [151-153]. Valadi et al. [154] made a key contribution when they demonstrated that both mRNA and miRNA could be exchanged between cells by virtue of exosomal transfer. Studying xenogenic cocultures, they observed expression of various mouse proteins in human mast cells after exosomal transfer from murine cells, indicating successful translation of exosomally delivered mRNA into protein. As with exosomes isolated from diverse cell types, MSC-derived exosomes are reported to contain lipid raft domains [155] and tetraspanins known to alter the fusion state of cell membranes (e.g., CD9, CD81), Alix, a calcium-binding protein with roles in both endosomal trafficking and cell death, and TSG101, a tumor suppressor protein [156, 157]. Compared with exosomes, which are relatively homogenous upon release, microvesicles are heterogenous in both size and composition. Furthermore, regulatory mechanisms for microvesicular shedding from the membrane surface remain poorly understood.

Exosomes purified from MSCs have garnered tremendous interest in the field of regenerative medicine based on their ability to reduce apoptosis/necrosis in rodents after ischemic injury to the heart $[158,159]$, brain $[160$, 161], lung [162], liver [163], or kidney [164]. In addition, exosomal transfer from MSCs is reported to reduce inflammation and to increase cell proliferation during tissue repair [162, 165, 166]. Tomasoni et al. [167] showed that MSCs transferred exosomes with mRNA for IGF1R and IGF1 to cisplatin-damaged proximal tubular cells; this resulted in their expression of IGF1R, thereby increasing sensitization to IGF-1. The exosomal transfer improved renal cell survival and increased proliferation during repair after injury. In multiple drug-induced models of liver injury, treatment with MSC exosomes at the time of injury increased the number of proliferating cell nuclear antigen-positive proliferation cells while reducing the number of hepatocytes undergoing apoptotic cell death [168]. Treatment of a murine carbon tetrachloride-based injury model with exosomes from human umbilical cord-derived MSCs was shown to reduce liver fibrosis [169]. Following stroke in rats, treatment with MSC-derived exosomes was shown to promote angiogenesis, neurogenesis, neurite outgrowth, and recovery by virtue of transfer of miR-133b [170, 171]. In addition to RNAs, exosomes and microvesicles can deliver peptide/protein-based paracrine effectors such as growth factors, cytokines, and hormones. For example, transfer of Wnt4 by exosomes from human umbilical cord-derived MSCs improved repair of skin wounds in rats by altering cell proliferation [172].

Currently, many investigators and clinicians are interested in the potential of MSC-derived EV therapeutics for repair of injured and diseased tissue and to treat cancer $[173,174]$. Most studies with exosome-based treatment of injured tissues/organs report positive outcomes, However, whether or not MSC-mediated transfer of exosomes, microvesicles, and/or their constituents promote or inhibit the activities of transformed cells in a way that would positively or negatively impact cancer remains contextdependent and controversial. For example, bone marrow MSCs were shown to reduce the growth of cultured breast cancer cells by transferring miR-127, $-197,-222$, and -223 through gap junctions and exosomes; these miRNAs are known to target CXCL12 (a.k.a. SDF-1) [175]. Lee et al. [176] suggested that exosomes from MSCs might suppress angiogenesis based on their containing miR-16, a miRNA that targets VEGF and was shown to reduce its expression in a breast cancer cell line. By contrast, Zhu et al. [177] reported that exosomes from human MSCs actually promoted tumor growth in vivo by inducing VEGF expression in tumor cells. Boelens et al. [178] reported cross-talk between stromal cells and breast cancer cells whereby stromal exosomes induced paracrine antiviral signals and stimulated juxtacrine Notch3 signaling that increased the number of therapy-resistant tumor-initiating cells. As with other paracrine effects of cell-based therapy or treatments based on administration of signaling agonists (e.g., growth factors), it is clear that care must be taken to avoid potential off-target treatment effects of administered EVs to avoid cancer cell propagation and/or metastasis.

Towards standardization of exosome-based therapy using MSCs or any cell type, identification of the most reliable and consistent vesicle isolation methods will be critical so that different laboratories can effectively compare their results. At present, several different methods 
of isolation are widely used, including centrifugation, filtration, immunoaffinity isolation with beads, and microfluidics. Notably, exosomes isolated from the same source by different methods may differ in amount and/or content [179-181].

Research aimed at improved understanding of mechanisms controlling cargo loading of exosomes will also be important. For protein-based cargo, Shen et al. [182] have reported some progress using expressed plasma membrane anchors. For miRNA-based cargo, VillarroyaBeltri et al. [183] recently identified specific miRNA sequence motifs that direct their loading into exosomes. Furthermore, they determined that sumoylated heterogenous nuclear ribonucleoprotein (hnRNPA2B1) was required for sorting of miRNAs into exosomes based on the specific motifs. Detailed characterization of MSC exosome content under various conditions and from all tissues will likely aid in a more predictable product in terms of therapy. For example, MSCs isolated from various tissues differ in terms of exosome content $[184,185]$ and MSCs from bone marrow with multiple myeloma were reported to differ in miRNA content relative to MSCs from control bone marrow [183].

\section{Conclusions}

In light of promising results in animal models and patients, therapeutic use of MSCs and MSC-based products for treatment of tissue injury and disease is likely to undergo continued evaluation. As next steps, focusing efforts toward achieving standardized methods of MSC isolation, characterization, and administration has great potential to provide powerful new treatments with MSCs or MSC-derived products. In regard to the predominant mechanisms of MSC function, clarification of the relative role(s) that each mechanism plays during the rescue and repair of damaged tissues/organs following MSC administration may serve to improve treatment safety, efficacy, and predictability of outcome for patients.

\section{Acknowledgments \\ This work was funded in part by research grants from the North American Spine Society (C.A.G.), The Scott \& White Research Grants Program (C.A.G.), The Texas Engineering Experiment Station Strategic Initiative (C.A.G.), The Center for the Advancement of Science in Space (C.A.G.), NSF Collaborative Research CBET-1264832 (C.A.G.), NIH NIAMS R01 AR066033 (C.A.G.), NIH NINDS/NIGMS R01 NS073815 (J.L.S.), NIH NHLBI R01 HL132264 (J.L.S.), and SPARK $^{V T}$ (J.L.S.).}

\section{Authors' contributions}

All authors wrote, read, and approved this manuscript.

\section{Competing interests}

The authors declare that they have no competing interests.

\section{Disclosures}

Jeffrey L. Spees is co-founder of Samba BioLogics, Inc. and Carl A. Gregory is a member of the Scientific Advisory Board of Theocorp Holding Co.

\section{Author details}

${ }^{1}$ University of Vermont, Burlington, VT, USA. ${ }^{2}$ Institute for Regenerative Medicine, Texas A \& M University College of Medicine, 206 Olsen Blvd., Room 228, MS1114, College Station, TX 77845, USA. ${ }^{3}$ Department of Medicine, Stem Cell Core, University of Vermont, 208 South Park Drive, Ste 2, Colchester, VT 05446, USA.

Published online: 31 August 2016

\section{References}

1. Friedenstein AJ, Ivanov-Smolenski AA, Chajlakjan RK, Gorskaya UF Kuralesova Al, Latzinik NW, Gerasimow UW. Origin of bone marrow stromal mechanocytes in radiochimeras and heterotopic transplants. Exp Hematol. 1978;6(5):440-4.

2. Friedenstein AJ. Precursor cells of mechanocytes. Int Rev Cytol. 1976;47:327-59.

3. Friedenstein AJ, Gorskaja JF, Kulagina NN. Fibroblast precursors in normal and irradiated mouse hematopoietic organs. Exp Hematol. 1976;4(5):267-74.

4. Friedenstein AJ, Chailakhjan RK, Lalykina KS. The development of fibroblast colonies in monolayer cultures of guinea-pig bone marrow and spleen cells. Cell Tissue Kinet. 1970:3(4):393-403.

5. Friedenstein AJ, Piatetzky II S, Petrakova KV. Osteogenesis in transplants of bone marrow cells. J Embryol Exp Morphol. 1966:16(3):381-90.

6. Pittenger $M$, Vanguri $P$, Simonetti $D$, Young R. Adult mesenchymal stem cells: potential for muscle and tendon regeneration and use in gene therapy. J Musculoskelet Neuronal Interact. 2002;2(4):309-20.

7. Prockop DJ. Marrow stromal cells as stem cells for nonhematopoietic tissues. Science. 1997;276(5309):71-4.

8. Caplan Al, Bruder SP. Mesenchymal stem cells: building blocks for molecular medicine in the 21st century. Trends Mol Med. 2001;7(6):259-64.

9. Horwitz EM, Gordon PL, Koo WK, Marx JC, Neel MD, McNall RY, Muul L, Hofmann T. Isolated allogeneic bone marrow-derived mesenchymal cells engraft and stimulate growth in children with osteogenesis imperfecta: Implications for cell therapy of bone. Proc Natl Acad Sci U S A. 2002;99(13):8932-7

10. Horwitz EM. Marrow mesenchymal cell transplantation for genetic disorders of bone. Cytotherapy. 2001;3(5):399-401.

11. Iso Y, Spees JL, Serrano C, Bakondi B, Pochampally R, Song YH, Sobel BE, Delafontaine P, Prockop DJ. Multipotent human stromal cells improve cardiac function after myocardial infarction in mice without long-term engraftment. Biochem Biophys Res Commun. 2007;354(3):700-6.

12. Hofstetter CP, Schwarz EJ, Hess D, Widenfalk J, El Manira A, Prockop DJ, Olson L. Marrow stromal cells form guiding strands in the injured spinal cord and promote recovery. Proc Natl Acad Sci U S A. 2002;99(4):2199-204.

13. Lee RH, Seo MJ, Pulin AA, Gregory CA, Ylostalo J, Prockop DJ. The CD34-like protein PODXL and alpha6-integrin (CD49f) identify early progenitor MSCS with increased clonogenicity and migration to infarcted heart in mice. Blood. 2009;113(4):816-26.

14. Lee RH, Pulin AA, Seo MJ, Kota DJ, Ylostalo J, Larson BL, Semprun-Prieto L, Delafontaine P, Prockop DJ. Intravenous hMSCs improve myocardial infarction in mice because cells embolized in lung are activated to secrete the anti-inflammatory protein TSG-6. Cell Stem Cell. 2009;5(1):54-63.

15. Dai W, Hale SL, Martin BJ, Kuang JQ, Dow JS, Wold LE, Kloner RA. Allogeneic mesenchymal stem cell transplantation in postinfarcted rat myocardium: short- and long-term effects. Circulation. 2005;112(2):214-23.

16. Herzog EL, Chai L, Krause DS. Plasticity of marrow-derived stem cells. Blood. 2003;102(10):3483-93.

17. Krause DS, Theise ND, Collector MI, Henegariu O, Hwang S, Gardner R, Neutzel S, Sharkis SJ. Multi-organ, multi-lineage engraftment by a single bone marrow-derived stem cell. Cell. 2001;105(3):369-77.

18. Theise ND. New principles of cell plasticity. C R Biol. 2002;325(10):1039-43.

19. Fuchs E, Segre JA. Stem cells: a new lease on life. Cell. 2000;100(1):143-55.

20. Wagers AJ, Weissman IL. Plasticity of adult stem cells. Cell. 2004;116(5):639-48.

21. Theise ND. On experimental design and discourse in plasticity research. Stem Cell Rev. 2005;1(1):9-13.

22. Gruh I, Martin U. Transdifferentiation of stem cells: a critical view. Adv Biochem Eng Biotechnol. 2009;114:73-106.

23. Prockop DJ, Oh JY. Medical therapies with adult stem/progenitor cells (MSCs): a backward journey from dramatic results in vivo to the cellular and molecular explanations. J Cell Biochem. 2012;113(5):1460-9. 
24. Prockop DJ. Repair of tissues by adult stem/progenitor cells (MSCs): controversies, myths, and changing paradigms. Mol Ther. 2009;17(6):939-46.

25. Bianco P, Cao X, Frenette PS, Mao JJ, Robey PG, Simmons PJ, Wang CY. The meaning, the sense and the significance: translating the science of mesenchymal stem cells into medicine. Nat Med. 2013;19(1):35-42.

26. Dexter TM, Spooncer E. Growth and differentiation in the hemopoietic system. Annu Rev Cell Biol. 1987;3:423-41.

27. Dexter TM, Wright EG, Krizsa F, Lajtha LG. Regulation of haemopoietic stem cell proliferation in long term bone marrow cultures. Biomedicine. 1977;27(9-10):344-9.

28. Dexter TM, Spooncer E, Toksoz D, Lajtha LG. The role of cells and their products in the regulation of in vitro stem cell proliferation and granulocyte development. J Supramol Struct. 1980;13(4):513-24.

29. Quesenberry PJ, Mcniece IK, McGrath HE, Temeles DS, Baber GB, Deacon DH. Stromal regulation of hematopoiesis. Ann N Y Acad Sci. 1989;554:116-24.

30. Le Blanc K, Tammik L, Sundberg B, Haynesworth SE, Ringdén O. Mesenchymal stem cells inhibit and stimulate mixed lymphocyte cultures and mitogenic responses independently of the major histocompatibility complex. Scand J Immunol. 2003;57(1):11-20.

31. Di Nicola M, Carlo-Stella C, Magni M, Milanesi M, Longoni PD, Matteucci P, Grisanti S, Gianni AM. Human bone marrow stromal cells suppress T-lymphocyte proliferation induced by cellular or nonspecific mitogenic stimuli. Blood. 2002;99(10):3838-43.

32. Aggarwal S, Pittenger MF. Human mesenchymal stem cells modulate allogeneic immune cell responses. Blood. 2005;105(4):1815-22.

33. Meisel R, Zibert A, Laryea M, Göbel U, Däubener W, Dilloo D. Human bone marrow stromal cells inhibit allogeneic T-cell responses by indoleamine 2,3-dioxygenase-mediated tryptophan degradation. Blood. 2004;103(12):4619-21.

34. Bartholomew A, Sturgeon C, Siatskas M, Ferrer K, Mclntosh K, Patil S, Hardy W, Devine S, Ucker D, Deans R, et al. Mesenchymal stem cells suppress lymphocyte proliferation in vitro and prolong skin graft survival in vivo. Exp Hematol. 2002;30(1):42-8

35. Tse WT, Pendleton JD, Beyer WM, Egalka MC, Guinan EC. Suppression of allogeneic T-cell proliferation by human marrow stromal cells: implications in transplantation. Transplantation. 2003;75(3):389-97.

36. Zappia E, Casazza S, Pedemonte E, Benvenuto F, Bonanni I, Gerdoni E, Giunti D, Ceravolo A, Cazzanti F, Frassoni F, et al. Mesenchymal stem cells ameliorate experimental autoimmune encephalomyelitis inducing T-cell anergy. Blood. 2005;106(5):1755-61.

37. Lyons $A B$, Parish CR. Determination of lymphocyte division by flow cytometry. J Immunol Methods. 1994;171(1):131-7.

38. Suni MA, Maino VC, Maecker HT. Ex vivo analysis of T-cell function. Curr Opin Immunol. 2005;17(4):434-40.

39. Akiyama K, Chen C, Wang D, Xu X, Qu C, Yamaza T, Cai T, Chen W, Sun L, Shi S. Mesenchymal-stem-cell-induced immunoregulation involves FAS-ligand-/FAS-mediated T cell apoptosis. Cell Stem Cell. 2012;10(5):544-55.

40. Hwu P, Du MX, Lapointe R, Do M, Taylor MW, Young HA. Indoleamine 2,3-dioxygenase production by human dendritic cells results in the inhibition of T cell proliferation. J Immunol. 2000;164(7):3596-9.

41. Mellor AL, Munn DH. Tryptophan catabolism and T-cell tolerance: immunosuppression by starvation? Immunol Today. 1999;20(10):469-73.

42. Ryan JM, Barry F, Murphy JM, Mahon BP. Interferon-gamma does not break, but promotes the immunosuppressive capacity of adult human mesenchymal stem cells. Clin Exp Immunol. 2007;149(2):353-63.

43. Waterman RS, Tomchuck SL, Henkle SL, Betancourt AM. A new mesenchymal stem cell (MSC) paradigm: polarization into a proinflammatory MSC1 or an Immunosuppressive MSC2 phenotype. PLoS One. 2010;5(4):e10088.

44. Ge W, Jiang J, Arp J, Liu W, Garcia B, Wang H. Regulatory T-cell generation and kidney allograft tolerance induced by mesenchymal stem cells associated with indoleamine 2,3-dioxygenase expression. Transplantation. 2010;90(12):1312-20

45. Sato K, Ozaki K, Oh I, Meguro A, Hatanaka K, Nagai T, Muroi K, Ozawa K. Nitric oxide plays a critical role in suppression of T-cell proliferation by mesenchymal stem cells. Blood. 2007;109(1):228-34.

46. Lepelletier $Y$, Lecourt S, Renand A, Arnulf B, Vanneaux V, Fermand JP, Menasché P, Domet T, Marolleau JP, Hermine O, et al. Galectin-1 and semaphorin-3A are two soluble factors conferring T-cell immunosuppression to bone marrow mesenchymal stem cell. Stem Cells Dev. 2010;19(7):1075-9.

47. Moresco EM, LaVine D, Beutler B. Toll-like receptors. Curr Biol. 2011;21(13):R488-93.

48. Watters TM, Kenny EF, O'Neill LA. Structure, function and regulation of the Toll/IL-1 receptor adaptor proteins. Immunol Cell Biol. 2007;85(6):411-9.

49. Tsyb AF, Petrov VN, Konoplyannikov AG, Saypina EV, Lepechina LA, Kalsina SS, Semenkova IV, Agaeva EV. In vitro inhibitory effect of mesenchymal stem cells on zymosan-induced production of reactive oxygen species. Bull Exp Biol Med. 2008;146(1):158-64.

50. Choi H, Lee RH, Bazhanov N, Oh JY, Prockop DJ. Anti-inflammatory protein TSG-6 secreted by activated MSCs attenuates zymosan-induced mouse peritonitis by decreasing TLR2/NF-kB signaling in resident macrophages. Blood. 2011;118(2):330-8

51. Kota DJ, Wiggins LL, Yoon N, Lee RH. TSG-6 produced by hMSCs delays the onset of autoimmune diabetes by suppressing Th1 development and enhancing tolerogenicity. Diabetes. 2013;62(6):2048-58.

52. Oh JY, Lee RH, Yu JM, Ko JH, Lee HJ, Ko AY, Roddy GW, Prockop DJ. Intravenous mesenchymal stem cells prevented rejection of allogeneic corneal transplants by aborting the early inflammatory response. Mol Ther. 2012;20(11):2143-52.

53. Németh K, Leelahavanichkul A, Yuen PS, Mayer B, Parmelee A, Doi K, Robey PG, Leelahavanichkul K, Koller BH, Brown JM, et al. Bone marrow stromal cells attenuate sepsis via prostaglandin E(2)-dependent reprogramming of host macrophages to increase their interleukin-10 production. Nat Med. 2009;15(1):42-9.

54. Maggini J, Mirkin G, Bognanni I, Holmberg J, Piazzón IM, Nepomnaschy I, Costa H, Cañones C, Raiden S, Vermeulen M, et al. Mouse bone marrow-derived mesenchymal stromal cells turn activated macrophages into a regulatory-like profile. PLoS One. 2010:5(2):e9252.

55. Bartosh TJ, Ylöstalo JH, Mohammadipoor A, Bazhanov N, Coble K, Claypool $\mathrm{K}$, Lee $\mathrm{RH}$, Choi H, Prockop DJ. Aggregation of human mesenchymal stromal cells (MSCs) into 3D spheroids enhances their antiinflammatory properties. Proc Natl Acad Sci U S A. 2010;107(31):13724-9.

56. Chen CP, Tsai PS, Huang CJ. Antiinflammation effect of human placental multipotent mesenchymal stromal cells is mediated by prostaglandin E2 via a myeloid differentiation primary response gene 88-dependent pathway. Anesthesiology. 2012;117(3):568-79.

57. Corcione A, Benvenuto F, Ferretti E, Giunti D, Cappiello V, Cazzanti F, Risso M, Gualandi F, Mancardi GL, Pistoia V, et al. Human mesenchymal stem cells modulate B-cell functions. Blood. 2006;107(1):367-72.

58. Asari S, Itakura S, Ferreri K, Liu CP, Kuroda Y, Kandeel F, Mullen Y. Mesenchymal stem cells suppress B-cell terminal differentiation. Exp Hematol. 2009;37(5):604-15.

59. Bochev I, Elmadjian G, Kyurkchiev D, Tzvetanov L, Altankova I, Tivchev P, Kyurkchiev S. Mesenchymal stem cells from human bone marrow or adipose tissue differently modulate mitogen-stimulated B-cell immunoglobulin production in vitro. Cell Biol Int. 2008;32(4):384-93.

60. Franquesa M, Hoogduijn MJ, Bestard O, Grinyó JM. Immunomodulatory effect of mesenchymal stem cells on B cells. Front Immunol. 2012;3:212.

61. Rosado MM, Bernardo ME, Scarsella M, Conforti A, Giorda E, Biagini S, Cascioli S, Rossi F, Guzzo I, Vivarelli M, et al. Inhibition of B-cell proliferation and antibody production by mesenchymal stromal cells is mediated by $\mathrm{T}$ cells. Stem Cells Dev. 2015;24(1):93-103.

62. Nemeth K, Keane-Myers A, Brown JM, Metcalfe DD, Gorham JD, Bundoc VG, Hodges MG, Jelinek I, Madala S, Karpati S, et al. Bone marrow stromal cells use TGF-beta to suppress allergic responses in a mouse model of ragweed-induced asthma. Proc Natl Acad Sci U S A. 2010;107(12):5652-7.

63. Liu Y, Wu J, Zhu Y, Han J. Therapeutic application of mesenchymal stem cells in bone and joint diseases. Clin Exp Med. 2014;14(1):13-24.

64. González MA, Gonzalez-Rey E, Rico L, Büscher D, Delgado M. Adipose-derived mesenchymal stem cells alleviate experimental colitis by inhibiting inflammatory and autoimmune responses. Gastroenterology. 2009:136(3):978-89.

65. Kusadasi N, Groeneveld AB. A perspective on mesenchymal stromal cell transplantation in the treatment of sepsis. Shock. 2013:40(5):352-7.

66. Cohen JA. Mesenchymal stem cell transplantation in multiple sclerosis. J Neurol Sci. 2013:333(1-2):43-9.

67. Bassi Ê, Moraes-Vieira PM, Moreira-Sá CS, Almeida DC, Vieira LM, Cunha CS, Hiyane MI, Basso AS, Pacheco-Silva A, Câmara NO. Immune regulatory properties of allogeneic adipose-derived mesenchymal stem cells in the 
treatment of experimental autoimmune diabetes. Diabetes. 2012;61(10):2534-45.

68. Baron F, Storb R. Mesenchymal stromal cells: a new tool against graft-versus-host disease? Biol Blood Marrow Transplant. 2012;18(6):822-40.

69. Ren G, Zhang L, Zhao X, Xu G, Zhang Y, Roberts Al, Zhao RC, Shi Y. Mesenchymal stem cell-mediated immunosuppression occurs via concerted action of chemokines and nitric oxide. Cell Stem Cell. 2008;2(2):141-50.

70. Sugiyama T, Nagasawa T. Bone marrow niches for hematopoietic stem cells and immune cells. Inflamm Allergy Drug Targets. 2012;11(3):201-6.

71. Sacchetti B, Funari A, Michienzi S, Di Cesare S, Piersanti S, Saggio I, Tagliafico E, Ferrari S, Robey PG, Riminucci M, et al. Self-renewing osteoprogenitors in bone marrow sinusoids can organize a hematopoietic microenvironment. Cell. 2007;131(2):324-36.

72. Murray IR, West CC, Hardy WR, James AW, Park TS, Nguyen A, Tawonsawatruk T, Lazzari L, Soo C, Péault B. Natural history of mesenchymal stem cells, from vessel walls to culture vessels. Cell Mol Life Sci. 2014;71(8):1353-74.

73. Crisan M, Yap S, Casteilla L, Chen CW, Corselli M, Park TS, Andriolo G, Sun B, Zheng $B$, Zhang $L$, et al. A perivascular origin for mesenchymal stem cells in multiple human organs. Cell Stem Cell. 2008;3(3):301-13.

74. Gregory CA. Mesenchymal stem cells: from culture to clinic. In: Levicar N, Habib N, Gordon M, Dimarakis I, editors. Stem cell repair and regeneration, vol. 3. London: Imperial College Press; 2008. p. 21-44.

75. Haynesworth SE, Baber MA, Caplan Al. Cytokine expression by human marrow-derived mesenchymal progenitor cells in vitro: effects of dexamethasone and IL-1 alpha. J Cell Physiol. 1996;166(3):585-92.

76. Cheng L, Hammond H, Ye Z, Zhan X, Dravid G. Human adult marrow cells support prolonged expansion of human embryonic stem cells in culture. Stem Cells. 2003;21(2):131-42.

77. Caplan Al, Dennis JE. Mesenchymal stem cells as trophic mediators. J Cell Biochem. 2006;98(5):1076-84

78. Silva WA, Covas DT, Panepucci RA, Proto-Siqueira R, Siufi JL, Zanette DL, Santos AR, Zago MA. The profile of gene expression of human marrow mesenchymal stem cells. Stem Cells. 2003;21(6):661-9.

79. Schinköthe T, Bloch W, Schmidt A. In vitro secreting profile of human mesenchymal stem cells. Stem Cells Dev. 2008;17(1):199-206.

80. Phinney DG, Hill K, Michelson C, DuTreil M, Hughes C, Humphries S, Wilkinson R, Baddoo M, Bayly E. Biological activities encoded by the murine mesenchymal stem cell transcriptome provide a basis for their developmental potential and broad therapeutic efficacy. Stem Cells. 2006;24(1):186-98.

81. Phinney DG. A SAGE view of mesenchymal stem cells. Int J Stem Cells. 2009;2(1):1-10.

82. Park HW, Shin JS, Kim CW. Proteome of mesenchymal stem cells. Proteomics. 2007;7(16):2881-94

83. Mangi AA, Noiseux N, Kong D, He H, Rezvani M, Ingwall JS, Dzau VJ. Mesenchymal stem cells modified with Akt prevent remodeling and restore performance of infarcted hearts. Nat Med. 2003;9(9):1195-201.

84. Mirotsou M, Zhang Z, Deb A, Zhang L, Gnecchi M, Noiseux N, Mu H, Pachori A, Dzau V. Secreted frizzled related protein 2 (Sfrp2) is the key Akt-mesenchymal stem cell-released paracrine factor mediating myocardial survival and repair. Proc Natl Acad Sci U S A. 2007;104(5):1643-8.

85. Gnecchi M, He H, Liang OD, Melo LG, Morello F, Mu H, Noiseux N, Zhang L, Pratt RE, Ingwall JS, et al. Paracrine action accounts for marked protection of ischemic heart by Akt-modified mesenchymal stem cells. Nat Med. 2005;11(4):367-8.

86. Noiseux N, Gnecchi M, Lopez-llasaca M, Zhang L, Solomon SD, Deb A, Dzau VJ, Pratt RE. Mesenchymal stem cells overexpressing Akt dramatically repair infarcted myocardium and improve cardiac function despite infrequent cellular fusion or differentiation. Mol Ther. 2006;14(6):840-50.

87. Tang YL, Zhao Q, Qin X, Shen L, Cheng L, Ge J, Phillips MI. Paracrine action enhances the effects of autologous mesenchymal stem cell transplantation on vascular regeneration in rat model of myocardial infarction. Ann Thorac Surg. 2005;80(1):229-36. discussion 236-227.

88. Miyahara Y, Nagaya N, Kataoka M, Yanagawa B, Tanaka K, Hao H, Ishino K, Ishida H, Shimizu T, Kangawa K, et al. Monolayered mesenchymal stem cells repair scarred myocardium after myocardial infarction. Nat Med. 2006;12(4):459-65.

89. Sassoli C, Pini A, Chellini F, Mazzanti B, Nistri S, Nosi D, Saccardi R, Quercioli F, Zecchi-Orlandini S, Formigli L. Bone marrow mesenchymal stromal cells stimulate skeletal myoblast proliferation through the paracrine release of VEGF. PLoS One. 2012;7(7):e37512.

90. Zhang M, Mal N, Kiedrowski M, Chacko M, Askari AT, Popovic ZB, Koc ON, Penn MS. SDF-1 expression by mesenchymal stem cells results in trophic support of cardiac myocytes after myocardial infarction. FASEB J. 2007;21(12):3197-207.

91. Sassoli C, Pini A, Mazzanti B, Quercioli F, Nistri S, Saccardi R, Zecchi-Orlandini S, Bani D, Formigli L. Mesenchymal stromal cells affect cardiomyocyte growth through juxtacrine Notch-1/Jagged-1 signaling and paracrine mechanisms: clues for cardiac regeneration. J Mol Cell Cardiol. 2011:51(3):399-408.

92. Iso Y, Rao KS, Poole CN, Zaman AK, Curril I, Sobel BE, Kajstura J, Anversa P, Spees JL. Priming with ligands secreted by human stromal progenitor cells promotes grafts of cardiac stem/progenitor cells after myocardial infarction. Stem Cells. 2014;32(3):674-83.

93. Bi B, Schmitt R, Israilova M, Nishio H, Cantley LG. Stromal cells protect against acute tubular injury via an endocrine effect. Clin J Am Soc Nephrol. 2007;18(9):2486-96.

94. Xing L, Cui R, Peng L, Ma J, Chen X, Xie RJ, Li B. Mesenchymal stem cells, not conditioned medium, contribute to kidney repair after ischemiareperfusion injury. Stem Cell Res Ther. 2014;5(4):101.

95. Zarjou A, Kim J, Traylor AM, Sanders PW, Balla J, Agarwal A, Curtis LM. Paracrine effects of mesenchymal stem cells in cisplatin-induced renal injury require heme oxygenase-1. Am J Physiol Renal Physiol. 2011;300(1):F254-62.

96. Togel F, Cohen A, Zhang P, Yang Y, Hu Z, Westenfelder C. Autologous and allogeneic marrow stromal cells are safe and effective for the treatment of acute kidney injury. Stem Cells Dev. 2009;18(3):475-85.

97. Togel F, Zhang P, Hu Z, Westenfelder C. VEGF is a mediator of the renoprotective effects of multipotent marrow stromal cells in acute kidney injury. J Cell Mol Med. 2009;13(8B):2109-14.

98. Jang HR, Park JH, Kwon GY, Lee JE, Huh W, Jin HJ, Choi SJ, Oh W, Oh HY, Kim YG. Effect of preemptive treatment with human umbilical cord blood-derived mesenchymal stem cells on the development of renal ischemia-reperfusion injury in mice. Am J Physiol Renal Physiol. 2014;307(10):F1149-61.

99. Imberti B, Morigi M, Tomasoni S, Rota C, Corna D, Longaretti L, Rottoli D, Valsecchi F, Benigni A, Wang J, et al. Insulin-like growth factor-1 sustains stem cell mediated renal repair. J Am Soc Nephrol. 2007;18(11):2921-8.

100. Deng YB, Ye WB, Hu ZZ, Yan Y, Wang Y, Takon BF, Zhou GQ, Zhou YF. Intravenously administered BMSCs reduce neuronal apoptosis and promote neuronal proliferation through the release of VEGF after stroke in rats. Neurol Res. 2010;32(2):148-56.

101. Chen L, Tredget EE, Wu PY, Wu Y. Paracrine factors of mesenchymal stem cells recruit macrophages and endothelial lineage cells and enhance wound healing. PLoS One. 2008;3(4):e1886.

102. Lee RH, Seo MJ, Reger RL, Spees JL, Pulin AA, Olson SD, Prockop DJ. Multipotent stromal cells from human marrow home to and promote repair of pancreatic islets and renal glomeruli in diabetic NOD/scid mice. Proc Natl Acad Sci U S A. 2006;103(46):17438-43.

103. Zeitouni S, Krause U, Clough BH, Halderman H, Falster A, Blalock DT, Chaput CD, Sampson HW, Gregory CA. Human mesenchymal stem cell-derived matrices for enhanced osteoregeneration. Sci Transl Med. 2012;4(132):132ra155.

104. Clough BH, McCarley MR, Krause U, Zeitouni S, Froese JJ, McNeill EP, Chaput CD, Sampson HW, Gregory CA. Bone regeneration with osteogenically enhanced mesenchymal stem cells and their extracellular matrix protein. J Bone Miner Res. 2014;30(1):83-94.

105. Lee RH, Yoon N, Reneau JC, Prockop DJ. Preactivation of human MSCs with TNF-alpha enhances tumor-suppressive activity. Cell Stem Cell. 2012;11(6):825-35.

106. Wynn TA. Cellular and molecular mechanisms of fibrosis. J Pathol. 2008:214(2):199-210.

107. Usunier B, Benderitter M, Tamarat R, Chapel A. Management of fibrosis: the mesenchymal stromal cells breakthrough. Stem Cells Int. 2014; $2014: 340257$.

108. Ortiz LA, Gambelli F, McBride C, Gaupp D, Baddoo M, Kaminski N, Phinney DG. Mesenchymal stem cell engraftment in lung is enhanced in response to bleomycin exposure and ameliorates its fibrotic effects. Proc Nat Acad Sci U S A. 2003;100(14):8407-11.

109. Ono M, Ohkouchi S, Kanehira M, Tode N, Kobayashi M, Ebina M, Nukiwa T, Irokawa T, Ogawa H, Akaike T, et al. Mesenchymal stem cells correct 
inappropriate epithelial-mesenchyme relation in pulmonary fibrosis using stanniocalcin-1. Mol Ther. 2014;23(3):549-60.

110. Huuskes BM, Wise AF, Cox AJ, Lim EX, Payne NL, Kelly DJ, Samuel CS, Ricardo SD. Combination therapy of mesenchymal stem cells and serelaxin effectively attenuates renal fibrosis in obstructive nephropathy. FASEB J. 2014; 29(2):540-53.

111. Rustom A, Saffrich R, Markovic I, Walther P, Gerdes HH. Nanotubular highways for intercellular organelle transport. Science. 2004;303(5660):1007-10.

112. Onfelt B, Nedvetzki S, Yanagi K, Davis DM. Cutting edge: membrane nanotubes connect immune cells. J Immunol. 2004;173:1511-3.

113. Onfelt B, Nedvetzki S, Benninger RK, Purbhoo MA, Sowinski S, Hume AN, Seabra MC, Neil MA, French PM, Davis DM. Structurally distinct membrane nanotubes between human macrophages support long-distance vesicular traffic or surfing of bacteria. J Immunol. 2006;177:8476-83.

114. Gurke S, Barroso JF, Hodneland E, Bukoreshtliev NV, Schlicker O, Gerdes HH. Tunneling nanotube (TNT)-like structures facilitate a constitutive, actomyosin-dependent exchange of endocytic organelles between normal rat kidney cells. Exp Cell Res. 2008;314:3669-83.

115. Bukoreshtliev NV, Wang X, Hodneland E, Gurke S, Barroso JF, Gerdes HH. Selective block of tunneling nanotube (TNT) formation inhibits intercellular organelle transfer between PC12 cells. FEBS Lett. 2009;583:1481-8.

116. Spees JL, Olson SD, Whitney MJ, Prockop DJ. Mitochondrial transfer between cells can rescue aerobic respiration. Proc Natl Acad Sci U S A. 2006;103:1283-8.

117. Plotnikov EY, Khryapenkova TG, Vasileva AK, Marey MV, Galkina SI, Isaev NK, Sheval EV, Polyakov WY, Sukhikh GT, Zorov DB. Cell-to-cell cross-talk between mesenchymal stem cells and cardiomyocytes in co-culture. J Cell Mol Med. 2008;12(5A):1622-31.

118. Liu K, Ji K, Guo L, Wu W, Lu H, Shan P, Yan C. Mesenchymal stem cells rescue injured endothelial cells in an in vitro ischemia-reperfusion model via tunneling nanotube like structure-mediated mitochondrial transfer. Microvasc Res. 2014;92:10-8.

119. Chinnery HR, Pearlman E, McMenamin PG. Membrane nanotubes in vivo: a feature of MHC class II+ cells in the mouse cornea. J Immunol. 2008; 180:5779-83.

120. Seyed-Razavi Y, Hickey MJ, Kuffová L, McMenamin PG, Chinnery HR. Membrane nanotubes in myeloid cells in the adult mouse cornea represent a novel mode of immune cell interaction. Immunol Cell Biol. 2013;91:89-95.

121. Rebbeck CA, Leroi AM, Burt A. Mitochondrial capture by a transmissible cancer. Science. 2011;331:303.

122. Thyssen G, Svab Z, Maliga P. Cell-to-cell movement of plastids in plants. Proc Natl Acad Sci U S A. 2012;109:2439-43.

123. Rice DW, Alverson AJ, Richardson AO, Young GJ, Sanchez-Puerta MV, Munzinger J, Barry K, Boore JL, Zhang Y, dePamphilis CW, et al. Horizontal transfer of entire genomes via mitochondrial fusion in the angiosperm Amborella. Science. 2013:342(6165):1468-73.

124. Islam MN, Das SR, Emin MT, Wei M, Sun L, Westphalen K, Rowlands DJ, Quadri SK, Bhattacharya S, Bhattacharya J. Mitochondrial transfer from bone-marrow-derived stromal cells to pulmonary alveoli protects against acute lung injury. Nat Med. 2012;18:759-65.

125. Li X, Zhang Y, Yeung SC, Liang Y, Liang X, Ding Y, Ip MS, Tse HF, Mak JC, Lian Q. Mitochondrial transfer of induced pluripotent stem cell-derived mesenchymal stem cells to airway epithelial cells attenuates cigarette smoke-induced damage. Am J Respir Cell Mol Biol. 2014;51:455-65.

126. Ahmad T, Mukherjee S, Pattnaik B, Kumar M, Singh S, Kumar M, Rehman R, Tiwari BK, Jha KA, Barhanpurkar AP, et al. Mirol regulates intercellular mitochondrial transport \& enhances mesenchymal stem cell rescue efficacy. EMBO J. 2014;33:994-1010.

127. Hoppins S, Lackner L, Nunnari J. The machines that divide and fuse mitochondria. Annu Rev Biochem. 2007;76:751-80.

128. Lackner LL. Shaping the dynamic mitochondrial network. BMC Biol. 2014;12:35.

129. Stowers RS, Megeath LJ, Górska-Andrzejak J, Meinertzhagen IA, Schwarz TL. Axonal transport of mitochondria to synapses depends on milton, a novel Drosophila protein. Neuron. 2002;36:1063-77.

130. Glater EE, Megeath LJ, Stowers RS, Schwarz TL. Axonal transport of mitochondria requires milton to recruit kinesin heavy chain and is light chain independent. J Cell Biol. 2006;173:545-57.

131. van Spronsen M, Mikhaylova M, Lipka J, Schlager MA, van den Heuvel DJ, Kuijpers M, Wulf PS, Keijzer N, Demmers J, Kapitein LC, et al. TRAK/Milton motor-adaptor proteins steer mitochondrial trafficking to axons and dendrites. Neuron. 2013;77:485-502.

132. Misko A, Jiang S, Wegorzewska I, Milbrandt J, Baloh RH. Mitofusin 2 is necessary for transport of axonal mitochondria and interacts with the Miro/ Milton complex. J Neurosci. 2010;30(12):4232-40.

133. Bohil AB, Robertson BW, Cheney RE. Myosin-X is a molecular motor that functions in filopodia formation. Proc Natl Acad Sci U S A. 2006;103:12411-6.

134. Gousset K, Marzo L, Commere PH, Zurzolo C. Myo10 is a key regulator of TNT formation in neuronal cells. J Cell Sci. 2013;126:4424-35.

135. Wang X, Schwarz TL. The mechanism of Ca2+-dependent regulation of kinesin-mediated mitochondrial motility. Cell. 2009;136:163-74.

136. Smith IF, Shuai J, Parker I. Active generation and propagation of Ca2+ signals within tunneling membrane nanotubes. Biophys J. 2011;100:L37-9.

137. Wang X, Veruki ML, Bukoreshtliev NV, Hartveit E, Gerdes HH. Animal cells connected by nanotubes can be electrically coupled through interposed gap-junction channels. Proc Natl Acad Sci U S A. 2010;107(40):17194-9.

138. Pekkurnaz G, Trinidad JC, Wang X, Kong D, Schwarz TL. Glucose regulates mitochondrial motility via Milton modification by O-GlcNAc transferase. Cell. 2014;158:54-68

139. Kimura S, Hase K, Ohno H. The molecular basis of induction and formation of tunneling nanotubes. Cell Tissue Res. 2013;352(1):67-76.

140. Théry C, Zitvogel L, Amigorena S. Exosomes: composition, biogenesis and function. Nat Rev Immunol. 2002;2(8):569-79.

141. Hase K, Kimura S, Takatsu H, Ohmae M, Kawano S, Kitamura H, Ito M, Watarai H, Hazelett CC, Yeaman C, Ohno H. M-Sec promotes membrane nanotube formation by interacting with Ral and the exocyst complex. Nat Cell Biol. 2009;11:1427-32.

142. Schiller C, Diakopoulos KN, Rohwedder I, Kremmer E, von Toerne C, Ueffing M, Weidle UH, Ohno H, Weiss EH. LST1 promotes the assembly of a molecular machinery responsible for tunneling nanotube formation. J Cell Sci. 2013;126:767-77.

143. Yu H, Koilkonda RD, Chou TH, Porciatti V, Ozdemir SS, Chiodo V, Boye SL, Boye SE, Hauswirth WW, Lewin AS, Guy J. Gene delivery to mitochondria by targeting modified adenoassociated virus suppresses Leber's hereditary optic neuropathy in a mouse model. Proc Natl Acad Sci U S A. 2012;109:E1238-47.

144. Koilkonda RD, Yu H, Chou TH, Feuer WJ, Ruggeri M, Porciatti V, Tse D, Hauswirth WW, Chiodo V, Boye SL, et al. Safety and effects of the vector for the Leber hereditary optic neuropathy gene therapy clinical trial. JAMA Ophthalmol. 2014;132:409-20.

145. Sowinski S, Jolly C, Berninghausen O, Purbhoo MA, Chauveau A, Köhler K, Oddos S, Eissmann P, Brodsky FM, Hopkins C, et al. Membrane nanotubes physically connect T cells over long distances presenting a novel route for HIV-1 transmission. Nat Cell Biol. 2008;10:211-9.

146. Gousset K, Schiff E, Langevin C, Marijanovic Z, Caputo A, Browman DT, Chenouard N, de Chaumont F, Martino A, Enninga J, et al. Prions hijack tunnelling nanotubes for intercellular spread. Nat Cell Biol. 2009:11:328-36.

147. Thayanithy V, Dickson EL, Steer C, Subramanian S, Lou E. Tumor-stromal cross talk: direct cell-to-cell transfer of oncogenic microRNAs via tunneling nanotubes. Transl Res. 2014;164(5):359-65

148. Lee Y, El Andaloussi S, Wood MJ. Exosomes and microvesicles: extracellular vesicles for genetic information transfer and gene therapy. Hum Mol Genet. 2012;21(R1):R125-34.

149. Raposo G, Stoorvogel W. Extracellular vesicles: exosomes, microvesicles, and friends. J Cell Biol. 2013:200(4):373-83.

150. Lai RC, Tan SS, Yeo RW, Choo AB, Reiner AT, Su Y, Shen Y, Fu Z, Alexander L, Sze SK, Lim SK. MSC secretes at least 3 EV types each with a unique permutation of membrane lipid, protein and RNA. J Extracell Vesicles. 2016;5:29828. doi:10.3402/jev.v5.29828. eCollection 2016.

151. Trams EG, Lauter CJ, Salem Jr N, Heine U. Exfoliation of membrane ecto-enzymes in the form of micro-vesicles. Biochim Biophys Acta. 1981:645(1):63-70.

152. Pan BT, Johnstone RM. Fate of the transferrin receptor during maturation of sheep reticulocytes in vitro: selective externalization of the receptor. Cell. 1983;33(3):967-78

153. Johnstone RM, Adam M, Hammond JR, Orr L, Turbide C. Vesicle formation during reticulocyte maturation. Association of plasma membrane activities with released vesicles (exosomes). J Biol Chem. 1987:262(19):9412-20.

154. Valadi H, Ekström K, Bossios A, Sjöstrand M, Lee JJ, Lötvall JO. Exosome-mediated transfer of mRNAs and microRNAs is a novel mechanism of genetic exchange between cells. Nat Cell Biol. 2007;9(6):654-9. 
155. Tan SS, Yin Y, Lee T, Lai RC, Yeo RW, Zhang B, Choo A, Lim SK. Therapeutic MSC exosomes are derived from lipid raft microdomains in the plasma membrane. J Extracell Vesicles. 2013;2. doi:10.3402/jev.v2i0.22614. eCollection 2013.

156. Mathivanan S, Simpson RJ. ExoCarta: A compendium of exosomal proteins and RNA. Proteomics. 2009:9(21):4997-5000.

157. Kim HS, Choi DY, Yun SJ, Choi SM, Kang JW, Jung JW, Hwang D, Kim KP, Kim DW. Proteomic analysis of microvesicles derived from human mesenchymal stem cells. J Proteome Res. 2012;11(2):839-49.

158. Lai RC, Arslan F, Lee MM, Sze NS, Choo A, Chen TS, Salto-Tellez M, Timmers L, Lee CN, El Oakley RM, et al. Exosome secreted by MSC reduces myocardial ischemia/reperfusion injury. Stem Cell Res. 2010;4(3):214-22.

159. Arslan F, Lai RC, Smeets MB, Akeroyd L, Choo A, Aguor EN, Timmers L, van Rijen HV, Doevendans PA, Pasterkamp G, et al. Mesenchymal stem cellderived exosomes increase ATP levels, decrease oxidative stress and activate PI3K/Akt pathway to enhance myocardial viability and prevent adverse remodeling after myocardial ischemia/reperfusion injury. Stem Cell Res. 2013;10(3):301-12.

160. Xin H, Li Y, Chopp M. Exosomes/miRNAs as mediating cell-based therapy of stroke. Front Cell Neurosci. 2014;8:377.

161. Xin H, Li Y, Cui Y, Yang JJ, Zhang ZG, Chopp M. Systemic administration of exosomes released from mesenchymal stromal cells promote functional recovery and neurovascular plasticity after stroke in rats. J Cereb Blood Flow Metab. 2013;33(11):1711-5.

162. Lee C, Mitsialis SA, Aslam M, Vitali SH, Vergadi E, Konstantinou G, Sdrimas K, Fernandez-Gonzalez A, Kourembanas S. Exosomes mediate the cytoprotective action of mesenchymal stromal cells on hypoxia-induced pulmonary hypertension. Circulation. 2012;126(22):2601-11.

163. Kanazawa H, Fujimoto Y, Teratani T, Iwasaki J, Kasahara N, Negishi K, Tsuruyama T, Uemoto S, Kobayashi E. Bone marrow-derived mesenchymal stem cells ameliorate hepatic ischemia reperfusion injury in a rat model. PLoS One. 2011;6(4):e19195.

164. Gatti S, Bruno S, Deregibus MC, Sordi A, Cantaluppi V, Tetta C, Camussi G. Microvesicles derived from human adult mesenchymal stem cells protect against ischaemia-reperfusion-induced acute and chronic kidney injury. Nephrol Dial Transplant. 2011;26(5):1474-83.

165. Bruno S, Grange C, Deregibus MC, Calogero RA, Saviozzi S, Collino F, Morando L, Busca A, Falda M, Bussolati B, et al. Mesenchymal stem cell-derived microvesicles protect against acute tubular injury. J Am Soc Nephrol. 2009;20(5):1053-67.

166. Zhang B, Yin Y, Lai RC, Tan SS, Choo AB, Lim SK. Mesenchymal stem cells secrete immunologically active exosomes. Stem Cells Dev. 2014;23(11):1233-44.

167. Tomasoni S, Longaretti L, Rota C, Morigi M, Conti S, Gotti E, Capelli C, Introna M, Remuzzi G, Benigni A. Transfer of growth factor receptor mRNA via exosomes unravels the regenerative effect of mesenchymal stem cells. Stem Cells Dev. 2013;22(5):772-80.

168. Tan CY, Lai RC, Wong W, Dan YY, Lim SK, Ho HK. Mesenchymal stem cell-derived exosomes promote hepatic regeneration in drug-induced liver injury models. Stem Cell Res Ther. 2014;5(3):76.

169. Li T, Yan Y, Wang B, Qian H, Zhang X, Shen L, Wang M, Zhou Y, Zhu W, Li $\mathrm{W}, \mathrm{Xu} \mathrm{W}$. Exosomes derived from human umbilical cord mesenchymal stem cells alleviate liver fibrosis. Stem Cells Dev. 2013;22(6):845-54.

170. Xin H, Li Y, Buller B, Katakowski M, Zhang Y, Wang X, Shang X, Zhang ZG, Chopp M. Exosome-mediated transfer of miR-133b from multipotent mesenchymal stromal cells to neural cells contributes to neurite outgrowth. Stem Cells. 2012;30(7):1556-64.

171. Xin H, Li Y, Liu Z, Wang X, Shang X, Cui Y, Zhang ZG, Chopp M. MiR-133b promotes neural plasticity and functional recovery after treatment of stroke with multipotent mesenchymal stromal cells in rats via transfer of exosome-enriched extracellular particles. Stem Cells. 2013;31(12):2737-46.

172. Zhang B, Wang M, Gong A, Zhang X, Wu X, Zhu Y, Shi H, Wu L, Zhu W, Qian H, Xu W. HucMSC-exosome mediated Wnt4 signaling is required for cutaneous wound healing. Stem Cells. 2014. doi:10.1002/stem.1771 [Epub ahead of print].

173. Baglio SR, Pegtel DM, Baldini N. Mesenchymal stem cell secreted vesicles provide novel opportunities in (stem) cell-free therapy. Front Physiol. 2012;3:359.

174. Akyurekli C, Le Y, Richardson RB, Fergusson D, Tay J, Allan DS. A systematic review of preclinical studies on the therapeutic potential of mesenchymal stromal cell-derived microvesicles. Stem Cell Rev. 2015;11(1):150-60. doi:10. 1007/s12015-014-9545-9.
175. Lim PK, Bliss SA, Patel SA, Taborga M, Dave MA, Gregory LA, Greco SJ, Bryan M, Patel PS, Rameshwar P. Gap junction-mediated import of microRNA from bone marrow stromal cells can elicit cell cycle quiescence in breast cancer cells. Cancer Res. 2011;71(5):1550-60.

176. Lee JK, Park SR, Jung BK, Jeon YK, Lee YS, Kim MK, Kim YG, Jang JY, Kim CW. Exosomes derived from mesenchymal stem cells suppress angiogenesis by down-regulating VEGF expression in breast cancer cells. PLoS One. 2013;8(12):e84256.

177. Zhu W, Huang L, Li Y, Zhang X, Gu J, Yan Y, Xu X, Wang M, Qian H, Xu W. Exosomes derived from human bone marrow mesenchymal stem cells promote tumor growth in vivo. Cancer Lett. 2012;315(1):28-37.

178. Boelens MC, Wu TJ, Nabet BY, Xu B, Qiu Y, Yoon T, Azzam DJ, Twyman-Saint Victor C, Wiemann BZ, Ishwaran $\mathrm{H}$, et al. Exosome transfer from stromal to breast cancer cells regulates therapy resistance pathways. Cell. 2014;159(3):499-513.

179. Tauro BJ, Greening DW, Mathias RA, Ji H, Mathivanan S, Scott AM, Simpson RJ. Comparison of ultracentrifugation, density gradient separation, and immunoaffinity capture methods for isolating human colon cancer cell line LIM1863-derived exosomes. Methods. 2012;56(2):293-304.

180. Kalra H, Simpson RJ, Ji H, Aikawa E, Altevogt $P$, Askenase $P$, Bond VC, Borràs FE, Breakefield X, Budnik V, et al. Vesiclepedia: a compendium for extracellular vesicles with continuous community annotation. PLoS Biol. 2012;10(12):e1001450.

181. Taylor DD, Shah S. Methods of isolating extracellular vesicles impact down-stream analyses of their cargoes. Methods. 2015. doi:10.1016/j.ymeth.2015.02.019 [Epub ahead of print].

182. Shen B, Wu N, Yang JM, Gould SJ. Protein targeting to exosomes/microvesicles by plasma membrane anchors. J Biol Chem. 2011;286(16):14383-95.

183. Villarroya-Beltri C, Gutiérrez-Vázquez C, Sánchez-Cabo F, Pérez-Hernández D, Vázquez J, Martin-Cofreces N, Martinez-Herrera DJ, Pascual-Montano A, Mittelbrunn M, Sánchez-Madrid F. Sumoylated hnRNPA2B1 controls the sorting of miRNAs into exosomes through binding to specific motifs. Nat Commun. 2013:4:2980.

184. Roccaro AM, Sacco A, Maiso P, Azab AK, Tai YT, Reagan M, Azab F, Flores LM, Campigotto F, Weller E, et al. BM mesenchymal stromal cell-derived exosomes facilitate multiple myeloma progression. J Clin Invest. 2013;123(4):1542-55.

185. Collino F, Deregibus MC, Bruno S, Sterpone L, Aghemo G, Viltono L, Tetta C, Camussi G. Microvesicles derived from adult human bone marrow and tissue specific mesenchymal stem cells shuttle selected pattern of miRNAs. PLoS One. 2010;5(7):e11803. 